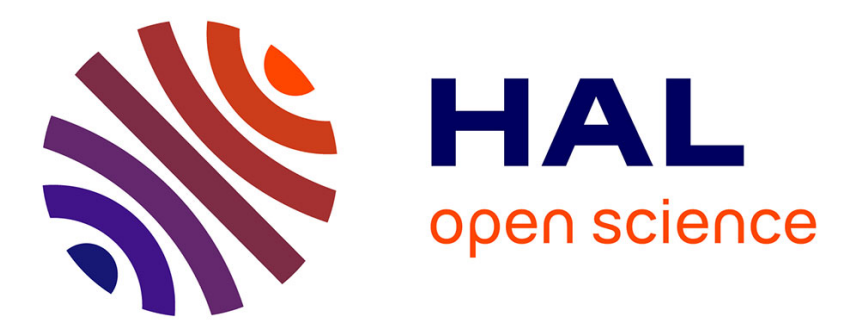

\title{
Synthesis of magnetite, ceria and magnetite-ceria materials by calcination of nanostructured precursor-minerals
}

\author{
German Montes-Hernandez
}

\section{- To cite this version:}

German Montes-Hernandez. Synthesis of magnetite, ceria and magnetite-ceria materials by calcination of nanostructured precursor-minerals. Materials Letters, 2020, 276, pp.128246. 10.1016/j.matlet.2020.128246 . hal-02896883

\section{HAL Id: hal-02896883 \\ https://hal.science/hal-02896883}

Submitted on 5 Nov 2020

HAL is a multi-disciplinary open access archive for the deposit and dissemination of scientific research documents, whether they are published or not. The documents may come from teaching and research institutions in France or abroad, or from public or private research centers.
L'archive ouverte pluridisciplinaire HAL, est destinée au dépôt et à la diffusion de documents scientifiques de niveau recherche, publiés ou non, émanant des établissements d'enseignement et de recherche français ou étrangers, des laboratoires publics ou privés. 


19

21

22

23

24

\section{Synthesis of Magnetite, Ceria and Magnetite-Ceria Materials by Calcination of Nanostructured Precursor-Minerals}

3

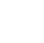

(1)

German Montes-Hernandez ${ }^{\mathrm{a}}$ *

${ }^{a}$ UGA, USMB, CNRS, IRD, IFSTTAR, ISTerre, 38000 Grenoble, France

9

(1)

12

3

14

15

6

7 *Corresponding author: German Montes-Hernandez

18 E-mail address: german.montes-hernandez@univ-grenoble-alpes.fr

20



The present short communication reports an original experimental calcination method to

27 synthesize magnetic materials with high thermal stability such as magnetite $\left(\mathrm{Fe}_{3} \mathrm{O}_{4}\right)$ with typical 28 spinel and atypical crystal shape, sub-micrometric rounded crystals of ceria $\left(\mathrm{CeO}_{2}\right)$ and magnetite29 ceria composites with varied shape and size of crystals; these latter depending on the nature of 30 mineral precursors (goethite, siderite or ferrihydrite). Herein, it was demonstrated that cooperative 31 redox reactions and simple vacuum can be used to synthesize magnetic composite materials by 32 calcination of nanostructured mineral precursors. In this way, bastnäsite mineral $\left(\mathrm{CeCO}_{3} \mathrm{~F}\right)$ is a 33 powerful reducing agent to synthesize magnetite from reductive dehydration of ferric 34 oxyhydroxides.

37 Keywords: Magnetic materials; Composites, Crystallization; Electron microscopy. 


\section{Introduction}

40 Synthetic ceria $\left(\mathrm{CeO}_{2}\right)$ and magnetite $\left(\mathrm{Fe}_{3} \mathrm{O}_{4}\right)$ are crucial oxides in many industrial and/or medical

41 applications related to their extraordinary chemical properties (acid-base and oxidation-reduction

42 behavior), thermal stability and oxygen mobility [1-6]. They have found their applications in

43 catalysis (photo-), luminescent materials, fuel cell, free radical scavenger, gas sensor, cosmetic

44 material, optical additives, polishing materials, water splitting, ceramic pigments, biomedicine,

45 magnetic storage media, etc. [1-6]. In general, magnetite or ceria are independently used; however,

46 recently their association as magnetite-ceria composites have been also explored in catalytic

47 reactions, for example, in the degradation of organic molecules [7], in Fenton reactions [8], in

48 multicomponent redox reactions [9] and in the dephosphorylation of phosphopeptides [10]. In this

49 way, the improving of existing methods and/or developing innovative routes to obtain well-

50 controlled crystal shapes and sizes remain important challenges in materials science. The present

51 short communication reports an original calcination method to synthesize magnetite, ceria and

52 magnetite-ceria composites with high thermal stability and probably with relevant catalytic

53 properties by using dynamic vacuum $\left(\approx 5 \times 10^{-6} \mathrm{mbar}\right)$ and bastnäsite $\left(\mathrm{CeCO}_{3} \mathrm{~F}\right)$ nanostructured

54 mineral as reducing agents. In fact, four nanostructured minerals goethite $(\mathrm{FeO}(\mathrm{OH}))$, siderite

$55\left(\mathrm{FeCO}_{3}\right)$, ferrihydrite 6-lines and bastnäsite $\left(\mathrm{CeCO}_{3} \mathrm{~F}\right)$ were synthesized at low $\mathrm{T}\left(<95^{\circ} \mathrm{C}\right)$, methods

56 already published by my group [11-14]. Then the obtained nanostructured minerals are used as

57 powdered precursors in order to synthesize magnetite from reductive dehydration of goethite or

58 from oxidative decarbonation of siderite, ceria from oxidative decarbonation of bastnäsite and

59 magnetite-ceria composites from cooperative and/or competitive redox reactions. Mineral

60 composition and crystal shape and size were mainly determined by XRD and FESEM. 


\subsection{Synthesis of mineral precursors and nano-magnetite reference}

63 Goethite, siderite, ferrihydrite and bastnäsite minerals were synthesized by using already published

64 methods [11-14]. In supplementary information, only the overall reaction of synthesis of precursor

65 and magnetite reference, including a basic characterization by XRD and FESEM are provided

66 (Figure SI-1).

67 2.2. Synthesis of magnetite, ceria and magnetite-ceria composites

\section{Magnetite from oxidative decarbonation of siderite}

$692 \mathrm{~g}$ of dry siderite placed in an alumina ceramic crucible were calcinated at $500^{\circ} \mathrm{C}$ under secondary

70 vacuum $\left(\approx 5 \times 10^{-6} \mathrm{mbar}\right)$ for $5 \mathrm{~h}$ by using a quartz tubular reactor. A heating rate of $30^{\circ} \mathrm{C} / \mathrm{min}$ was

71 performed in all experiments. At the end of experiment, the calcinated product were cooled under

72 dynamic vacuum at room temperature $\left(\sim 19^{\circ} \mathrm{C}\right)$.

73 Magnetite from reductive dehydration of goethite

$741 \mathrm{~g}$ of dry goethite and $1 \mathrm{~g}$ of dry bastnäsite placed independently in an alumina ceramic crucible

75 (e.i. without solid-solid contact) were calcinated at the same above conditions. In this case, the

76 bastnäsite transformation into ceria $\left(\mathrm{CeO}_{2}\right)$ improves the reducing conditions in the reactor

77 allowing complete goethite transformation into magnetite.

78 Ceria from oxidative decarbonation of bastnäsite

$792 \mathrm{~g}$ of dry bastnäsite placed in an alumina ceramic crucible were calcinated at the same above 
conditions.

82 Three different binary mineral-precursor mixtures (ferrihydrite-bastnäsite, goethite-bastnäsite and

83 siderite-bastnäsite) were manually prepared by using equivalent weighs in an agate mortar and

84 mixed by a pestle. Then, $2 \mathrm{~g}$ of each mineral mixture were placed in an alumina ceramic crucible

85 and calcinated at the same above conditions.

86 All calcinated solid products were manually recovered and stored in plastic flasks for subsequent

87 characterization by XRD and FESEM (see supplementary information).

\section{3. Results and Discussion}

90 All main results are summarized in Figures 1 to 3 concerning particularly FESEM images and DRX

91 patterns of calcinated products. Based on this conventional solid characterization for precursors

92 (Figure SI-1) and calcinated products, an overall redox reaction for each investigated scenario is

93 suggested as follows:

$94 \quad$ Magnetite formation from goethite

$95 \quad 3 \mathrm{FeOOH} \Rightarrow \mathrm{Fe}_{3} \mathrm{O}_{4}+0.25 \mathrm{O}_{2}+1.5 \mathrm{H}_{2} \mathrm{O}$

96 The formation of magnetite is improved when bastnäsite mineral is used as supplementary reducing

97 agent in the reactor (see Figure SI-2). In such case, the $\mathrm{Ce}$ (III) oxidation to $\mathrm{Ce}(\mathrm{IV}$ ) initially

98 contained in cerium carbonate creates a most reducing atmosphere into the reactor during

99 calcination process. FESEM images have revealed two crystals shapes of magnetite, typical spinel

100 shape and acicular crystals; letter shape was probably inherited from original goethite shape (Figure 5 
1).

Magnetite formation from siderite decarbonation

103

$3 \mathrm{FeCO}_{3}+0.5 \mathrm{O}_{2} \Rightarrow \mathrm{Fe}_{3} \mathrm{O}_{4}+3 \mathrm{CO}_{2}$

104 The constrained dynamic vacuum was enough to favor the magnetite formation rather than 105 hematite $\left(\mathrm{Fe}_{2} \mathrm{O}_{3}\right)$. Assuming that water is also present in the system (residual water in vacuum 106 atmosphere), the following oxidative reaction $\left(3 \mathrm{FeCO}_{3}+\mathrm{H}_{2} \mathrm{O} \Rightarrow \mathrm{Fe}_{3} \mathrm{O}_{4}+3 \mathrm{CO}_{2}+\mathrm{H}_{2}\right)$ could also 107 contribute to magnetite formation. Surprisingly, synthesize magnetite have conserved the initial 108 shape of siderite spherical aggregates as revealed by FESEM, however, the magnetite micrometric $109(<3 \mu \mathrm{m})$ spherical agglomerates constituted by magnetite nanoparticles are now observed (Figure $1101)$.

$1122 \mathrm{CeCO}_{3} \mathrm{~F}+\mathrm{O}_{2} \Rightarrow 2 \mathrm{CeO}_{2}+2 \mathrm{CO}_{2}+\mathrm{F}_{2}$

113 This reaction can be auto-enhanced by in situ produced flour than can react with residual water in 114 the system to form additional oxidants (e.g. $\mathrm{F}_{2}+\mathrm{H}_{2} \mathrm{O} \Rightarrow 0.5 \mathrm{O}_{2}+2 \mathrm{HF}$ ). However, the XRD has 115 also revealed cerium oxide fluoride $(\mathrm{CeOF})$ that is generally a transient phase during ceria 116 formation from oxidative decarbonation of bastnäsite $\left(\mathrm{CeCO}_{3} \mathrm{~F} \Rightarrow \mathrm{CeOF}+\mathrm{CO}_{2}\right)$ with a short 117 lifetime under air atmosphere as already demonstrated [12]. Finally, FESEM images have revealed 118 rounded ceria nanoparticles with high agglomeration degree with respect to ceria formed under air 119 atmosphere (see Figure 2).

120 Magnetite-Ceria composite from ferrihydrite-bastnäsite mixture

$2 \mathrm{CeCO}_{3} \mathrm{~F}+\mathrm{O}_{2} \Rightarrow 2 \mathrm{CeO}_{2}+2 \mathrm{CO}_{2}+\mathrm{F}_{2}$ 
123 A complete transformation of ferrihydrite into magnetite was particularly possible by means of

124 cerium oxidation contained in bastnaesite. This means that a cooperative double-redox reaction 125 exists: $\mathrm{Fe}^{3+} / \mathrm{Fe}^{2+}$ and $\mathrm{O}^{2-} / \mathrm{O}_{2}$ for magnetite formation and $\mathrm{Ce}^{3+} / \mathrm{Ce}^{4+}, \mathrm{O}_{2} / \mathrm{O}^{2-}$ and $\mathrm{F}^{-} / \mathrm{F}_{2}$ for ceria

126 formation. In terms of mineral composition, the XRD has revealed magnetite and ceria as major 127 phases and a minor proportion of cerium oxide fluoride (CeOF) and sodium fluoride (NaF) were 128 also detected in final products, indicating an incomplete oxidation of cerium initially contained in 129 bastnäsite mesocrystals (see XRD patterns in Figure 3). FESEM images have revealed 130 homogeneous mixture of micrometer magnetite crystal $(<2 \mu \mathrm{m})$ with spinel shape and sub131 micrometric ceria crystals with rounded shape. Ceria particles adhered onto magnetite crystals or 132 forming aggregates.

133 Magnetite-Ceria composite from goethite-bastnäsite mixture

$134 \quad 3 \mathrm{FeOOH} \Rightarrow \mathrm{Fe}_{3} \mathrm{O}_{4}+0.25 \mathrm{O}_{2}+1.5 \mathrm{H}_{2} \mathrm{O}$

$1352 \mathrm{CeCO}_{3} \mathrm{~F}+\mathrm{O}_{2} \Rightarrow 2 \mathrm{CeO}_{2}+2 \mathrm{CO}_{2}+\mathrm{F}_{2}$

136 This cooperative double redox reaction is identical to ferrihydrite-bastnäsite system, however,

137 different crystal shape and size and different water content exist between goethite and ferrihydrite

138 (see Figure SI-1). As expected, magnetite-ceria composite was synthesized as revealed from XRD

139 patterns. In this case, sub-micrometric magnetite crystals with spinel shape are homogeneously 140 mixed with nanometric ceria rounded-crystals having high agglomeration and/or aggregation 141 degree as observed in the FESEM image (Figure 3).

142 Magnetite-Ceria composite from siderite-bastnäsite mixture

$143 \quad 3 \mathrm{FeCO}_{3}+0.5 \mathrm{O}_{2} \Rightarrow \mathrm{Fe}_{3} \mathrm{O}_{4}+3 \mathrm{CO}_{2}$

$1442 \mathrm{CeCO}_{3} \mathrm{~F}+\mathrm{O}_{2} \Rightarrow 2 \mathrm{CeO}_{2}+2 \mathrm{CO}_{2}+\mathrm{F}_{2}$ 
145 Contrary to two above cooperative redox systems, here, an oxidative-decarbonation competition

146 exists as illustrated in reactions $6 \mathrm{a}$ and 6b. Despite this competition, the magnetite-ceria composite 147 was successfully synthesized as revealed by XRD (Figure 3). However, a more reducing 148 environment in the reactor was created because a higher proportion of cerium oxide fluoride $149(\mathrm{CeOF})$ and also iron oxide $(\mathrm{FeO})$ were detected; both mineral phases implying only decarbonation 150 process without oxidation, possible only in high reducing systems. FESEM images have revealed 151 sub-micrometric magnetite and ceria crystals with rounded shape and with high agglomeration 152 degree (see Figure 3 and Figure SI-3).

153

154 4. Conclusion

155 Magnetite with typical spinel and atypical crystal shape, sub-micrometric rounded crystals of ceria 156 and magnetite-ceria composites with varied shape and size of crystals were synthesized by 157 calcination under dynamic secondary vacuum and using bastnäsite as complementary solid 158 reducing agent. 
166 The authors are grateful to CNRS and UGA for providing funding support. IPAG is grateful for 167 allowing the access to calcination experiments. We thank Nathaniel Findling, Olivier Brissaud, 168 Pierre Beck and Eric Quirico for their technical assistance. 


\section{References}

188

189

190

191

192

193

194

195

196

197

198

199

200

201

202

203

204

205

206

[1] A. Bumajdad, J. Eastoe, A. Mathew, Cerium oxide nanoparticles prepared in self-assembled systems, Adv. Colloid Interface Sci. 147-148 (2009) 56-66.

[2] E. Leino, P. Maki-Arvela, V. Eta, N. Kumar, F. Demoisson, A. Samikannu, A. R. Leino, A. Shchukarev, D. Y. Murzin, J. P. Mikkola, The influence of various synthesis methods on the catalytic activity of cerium oxide in one-pot synthesis of diethyl carbonate starting from $\mathrm{CO} 2$, ethanol and butylene oxide, Catalysis Today 210 (2013) 47-54.

[3] N. Gokon, S. Sagawa, T. Kodoma, Comparative study of activity of cerium oxide at thermal reduction temperatures of $1300-1550{ }^{\circ} \mathrm{C}$ for solar thermochemical two-step water-splitting cycle, Int. J. Hydrogen Energy 38 (2013) 14402-14414.

[4] J. Mosayebi, M. Kiyasatfar, S. Laurent, Synthesis, functionalization, and design of magnetic nanoparticles for theranostic applications, Adv. Healthcare Mater. (2017) 1700306

[5] M. Usman, J. M. Byrne, A. Chaudhary, S. Orsetti, K. Hanna, C. Ruby, A. Kappler, S. B. Haderlein, Magnetite and green Rust: synthesis, properties, and environmental applications of mixed-valent iron minerals, Chem. Rev. 118 (2018) 3251-3304.

[6] J. Jolivet, C. Chanéac, E. Tronc, Iron oxide chemistry. From molecular clusters to extended solid networks, Chem. Commun. (2004) 481-487.

[7] G. Gan, P. Zhao, X. Zhang, J. Liu, J. Liu, C. Zhang, X. Hou, Degradation of Pantoprazole in aqueous solution using magnetic nanoscaled $\mathrm{Fe} 3 \mathrm{O} 4 / \mathrm{CeO} 2$ composite: Effect of system parameters and degradation pathway, J. Alloy. Compd. 725 (2017) 472-483. 
208 Heterogeneous Catalyst for Degradation of 4-Chlorophenol, Environ. Sci. Technol. 46, (2012) 209 10145-10153.

210 [9] M. B. Gawande, V. D. B. Bonifácio, R. S. Varma, I. D. Nogueira, N. Bundaleski, C. A. A. 211 Ghumman, O. M. N. D. Teodoro, P. S. Branco, Magnetically recyclable magnetite-ceria (Nanocat212 Fe-Ce) nanocatalyst - applications in multicomponent reactions under benign conditions, Green 213 Chem. 15, (2013) 1226-1231.

214 [10] Q. Min, S. Li, X. Chen, E. S. Abdel-Halim, L.-P. Jiang, J.-J. Zhu, Magnetite/ceria-codecorated 215 titanoniobate nanosheet: A 2D catalytic nanoprobe for efficient enrichment and programmed 216 dephosphorylation of phosphopeptides, ACS Appl. Mater. Interfaces 7 (2015) 9563-9572.

217 [11] S. Hajji, G. Montes-Hernandez, G. Sarret, A. Tordo, G. Morin, G. Ona-Nguema, S. Bureau, 218 T. Turki, M. Nzoughi, Arsenite and chromate sequestration onto ferrihydrite, siderite and goethite 219 nanostructured minerals: Isotherms from flow-through reactor experiments and XAS 220 measurements, J. Hazard. Mater. 362 (2019) 358-367.

221 [12] G. Montes-Hernandez, R. Chiriac, N. Findling, F. Toche, F. Renard, Synthesis of Ceria $\left(\mathrm{CeO}_{2}\right.$ 222 and $\mathrm{CeO}_{2-\mathrm{x}}$ ) Nanoparticles via Decarbonation and $\mathrm{Ce}(\mathrm{III})$ Oxydation of Synthetic Bastnäsite 223 (CeCO3F,. Mater. Chem. Phys. 172 (2016) 202-210.

224 [13] G. Montes-Hernandez, P. Beck, F. Renard, E. Quirico, B. Lanson, R. Chiriac, N. Findling, 225 Fast precipitation of acicular goethite from ferric hydroxide gel under moderate temperature (30 226 and 70 C degrees), Cryst. Growth Des. 11 (2011) 2264-2272. 
227 [14] G. Montes-Hernandez, F. Renard, Time-resolved in situ Raman spectroscopy of the nucleation

228 and growth of siderite, magnesite and calcite and their precursors, Cryst. Growth Des. 16 (2016)

$229 \quad 7218-7230$.

230

231

232

233

234

235

236

237

238

239

240

241

242

243 


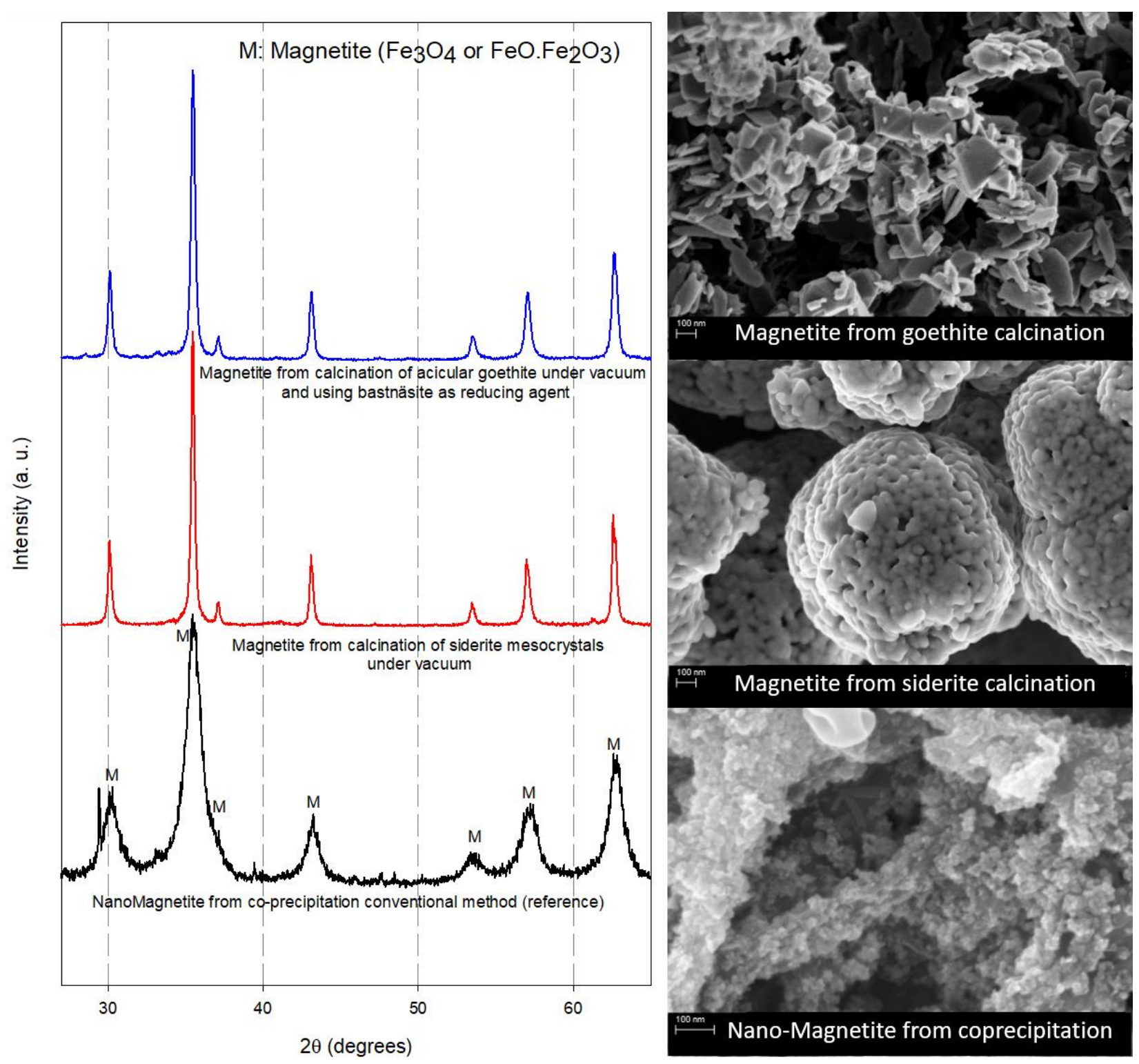

247 Figure 1. XRD patterns for three magnetite synthesized for three different reaction pathways and

248 FESEM images showing shape and size of magnetite crystals. 

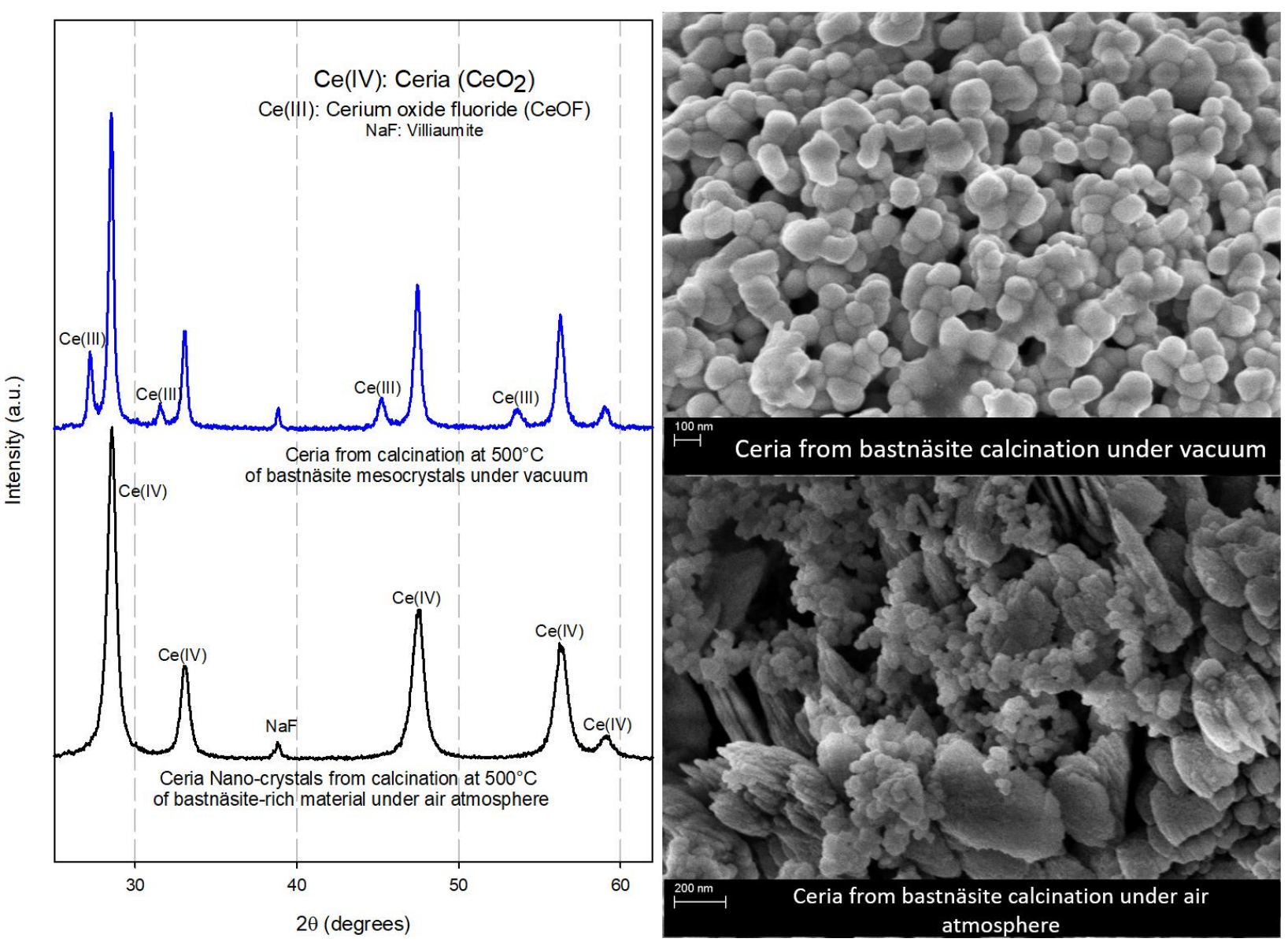

251 Figure 2. XRD patterns for two ceria synthesized under air atmosphere (reference) and under dynamic vacuum and FESEM images showing shape and size of ceria crystals. 

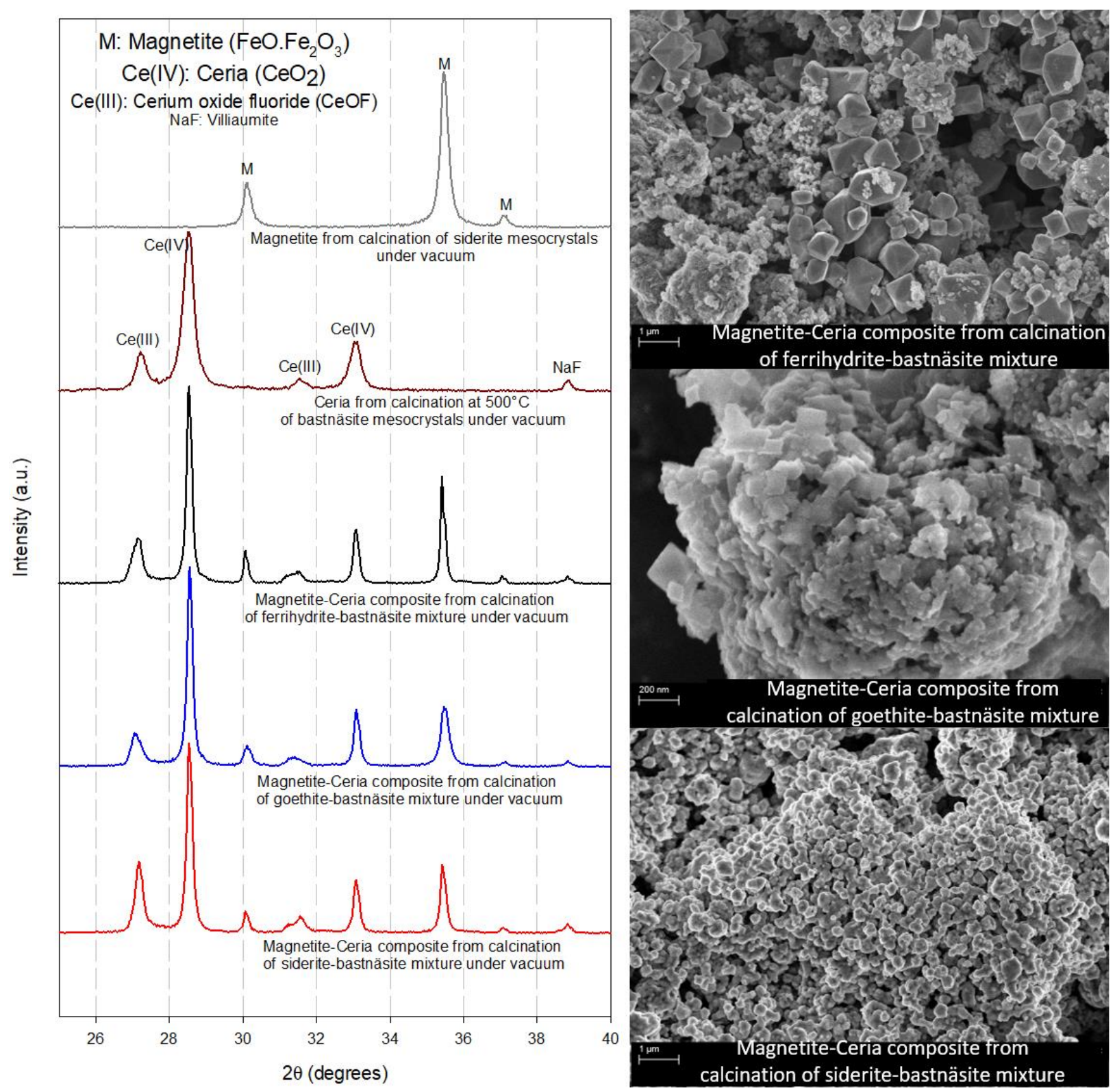

257 Figure 3. XRD patterns for three magnetite-ceria composite materials synthesized by calcination

258 of three different mineral-precursor mixtures and FESEM images showing shape and size of

259 magnetite crystals. 